Atıf İçin: Çalımlı, MH, 2021. Su Ortamından Ultrasonik Koşullar Altında GO Malzemesine Yüklenen Bimetalik Pt / Co ile Maxilon Blue 5G Kaldırma. Iğdır Üniversitesi Fen Bilimleri Enstitüsü Dergisi, 11(2): 1362-1373.

To Cite: Çalımlı, MH, 2021. Maxilon Blue 5G Removal by Bimetallic Pt/Co Loaded on GO Material under Ultrasonic Conditions from Aquatic Medium. Journal of the Institute of Science and Technology, 11(2): 1362-1373.

\title{
Maxilon Blue 5G Removal by Bimetallic Pt/Co Loaded on GO Material under Ultrasonic Conditions from Aquatic Medium
}

\author{
Mehmet Harbi ÇALIMLI ${ }^{1 *}$
}

\begin{abstract}
Bimetallic Pt/Co loaded on GO adsorbance was produced following a series of simple hydrothermal methods. The produced bimetallic Pt/Co loaded GO material was used in the maxilon blue 5G removal (MB 5G) and investigated its adsorption studies. The adsorption studies on removal of MB 5G using the bimetallic $\mathrm{Pt} / \mathrm{Co}$ loaded on GO material were carried out performing different experimental conditions like ultrasonic irradiation time (1-120 min), temperature $\left(24-55^{\circ} \mathrm{C}\right)$, initial MB $5 \mathrm{G}$ concentration $\left(0.7 .10^{-5}-1.5 .10^{-5}\right.$ $\mathrm{M}$ ), and $\mathrm{pH}$ (4-10) to detect optimum removal conditions. The reaction kinetics were investigated by pairing the so-called first-order pseudo-second-order and intraparticle diffusion in the adsorption process study. In addition, enthalpy, entropy and Gibbs free energy, and thermodynamic activation functions were investigated in order to understand the adsorption mechanism. These data showed that the bimetallic Pt/Co loaded on GO material can be used as an effective nano adsorbent for the removal of MB 5G as an organic pollutant in an aquatic medium.
\end{abstract}

Keywords: Bimetallic, adsorption, removal, kinetic, Maxilon Blue $5 \mathrm{G}$

\section{Su Ortamından Ultrasonik Koşullar Altında GO Malzemesine Yüklenen Bimetalik Pt / Co ile Maxilon Blue 5G Kaldırma}

ÖZET: Bimetalik Pt/Co'nin GO üzerine yüklenmiş adsorbent bir seri hidrotermal metod ile sentezlendi. Elde edilen adsorbance maxilon blue 5G (MB 5G)'inin giderilmesinde kullanıldı ve adsorbsiyon çalışmaları incelendi. MB 5G'inin Pt/Co yüklü GO material ile yapılan adsorbsiyon çalışmaları farklı deneysel durumlarda olan ultrasonic 1şıma zamanı (1-120 min), sıcaklık (24-55 $\left.{ }^{\circ} \mathrm{C}\right)$, başlangıç MB 5G konstrasyonu $\left(0.7 .10^{-5}-1.5 .10^{-5} \mathrm{M}\right)$, ve pH (4-10) gibi deneysel koşullar altında yapıldı. Kinetik reaksiyonlar birinci dereceden, ikinci dereceden ve intrapartikül düfüzyonu metodları ile incelendi. Buna ilaveten, entalpi, entropi, Gibbs serbest enerjisi ve termodinamik aktivasyon fonksiyoları aktivasyon mekanizmasını tespit etmek için incelendi. Elde edilen sonuçlar ile bimetallik Pt/Co'nin GO üzerine yüklenmiş adsorbent MB 5G organik boyasının giderilmesinde etkin bir şekilde kullanılabileceği sonucuna varıldı.

Anahtar Kelimeler: Bimetalik, adsorpsiyon, uzaklaştırma, kinetik, Maxilon Blue 5G

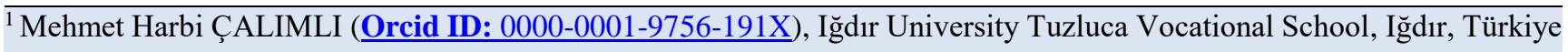
*Sorumlu Yazar / Corresponding author: Mehmet Harbi ÇALIMLI, mharbi.calimli@igdir.edu.tr
} 


\section{INTRODUCTION}

Dyestuffs are used in different areas such as textile, leather, paper, and plastic and are given to the environment as wastewater (Chiou et al., 2004). It is not easy to remove dye-containing wastewater from the environment. Because these dyes gain a stable structure as a result of interaction with light, heat and oxidizing agents and become resistant (Crini, 2006). However, waste dyes contain many toxic materials in their structure(Yener et al., 2006). When the textile industry is compared for both volumetric discharge and other different reasons, it is thought that the waste water is very polluted (Singh et al., 2003). Different technological application processes are used to deal with such problems (Banat et al., 1996; Choy et al., 1999). Chemical oxidation, membrane filtration, biological degradation, separation and adsorption techniques are the most preferred treatment process systems for dye removal (YenisoyKarakaş et al., 2004). In this study, the adsorption technique was preferred under ultrasonic process conditions for dye removal. This processing method was effective in its use because it is easy to apply, very fast, and cost-effective (Zhang et al., 2013). Adsorption process technique, efficiency changes depending on the physical and chemical properties of the adsorbent (Yagub et al., 2014; YenisoyKarakaş et al., 2004). So far, different composite materials like krill clay, polymer based composites, diatomite, graphene oxide, chitosan and green clay (M. H. Çalımlı, 2020; Mehmet Harbi Çalımlı et al., 2018; Demirbaş et al., 2019, 2016; Nas et al., 2017; Şen et al., 2018) have been applied to remove organic base pollutants like dyes from aquatic environments. In recent studies, nanoparticles produced using polymer, carbon, different metals as new sorbents are highly preferred (Mittal et al., 2014; R. Wu et al., 2014). Since discovered, graphene oxide (GO) was applied in many different areas like high-quality electronics, magnetic, thermal and optical (Batra et al., 2015; Fonseca et al., 2015; Z. Liu et al., 2008). Because, it has extraordinary properties such as (Novoselov et al., 2004; Roy-Mayhew et al., 2014; W. Zhao et al., 2015). In addition, graphene material has a strong interest in many areas such as battery and sensor, electrochemistry, supercapacitor technology and adsorption process applications (Feng et al., 2015; Y. Liu et al., 2011; Song et al., 2016; Teixeira et al., 2016). Graphene material has been widely produced as a catalyst support in works involving metal alloys such as $\mathrm{Co}, \mathrm{Ni}, \mathrm{Cr}$ and $\mathrm{Fe}$ (Haldorai et al., 2014; Hernández-Fernández et al., 2007; Koffi et al., 2005; Lai et al., 2010; S. H. Liu et al., 2011; Shen et al., 2010; J. Zhao et al., 2011). Herein, we synthesized bimetallic Pt/Co loaded on GO material to remove MB 5G dye. The data obtained showed that bimetallic Pt/Co loaded on GO material can be effective in $\mathrm{MB} 5 \mathrm{G}$ removal under ultrasonic conditions from the aqueous medium. As stated in the literature, MB 5G is mixed with natural resources as a result of use in industrial activities. This paint is highly damaging to the aquatic environment and aquatic life. For the first time in our study, Bimetallic Pt / Co Loaded on GO material was used to remove MB 5G dye. With this study, the optimum conditions were determined and experimental findings were made about what conditions should be created for the removal of $\mathrm{MB} 5 \mathrm{G}$ dye.

\section{MATERIAL AND METHODS}

\section{Chemical material}

$\mathrm{PtCl}_{4}$ (99\%), $\mathrm{CoCl}_{2}>$ 99\%, MG 5G dyestuff, ethanol, superhydride and graphite chemicals were obtained from Sigma Aldrich. All chemicals are analytical grade and were used in runs without any purification process. All glassware used in the study was cleaned using distilled water and ethanol.

\section{Preparation and characterization of bimetallic Pt/Co loaded GO material}

For bimetallic Pt/Co loaded GO material synthesis, $\mathrm{CoCl}_{2}$ and $\mathrm{PtCl}_{4}$ are used as precursors, and $0.25 \mathrm{mmol}$ of each taken and solved in $5 \mathrm{ml}$ deionized water. This mixture was mixed in an ultrasonic 
bath for 10 minutes. Afterward, the required GO has added the resulting mixture. The mixture was stirred for $2 \mathrm{~h}$. Then, ethanol and super hydride were added to the resulting slurry. Upon being the visible brownish color of the solution, (that shows reduction completion of metal ions to metallic state), the formed solid sample was filtered. The solid sample was washed with copious amounts of distilled water $(3 \times 10 \mathrm{~mL})$, rinsed using ethanol. Afterward, this solid sample was dried in an oven at $80^{\circ} \mathrm{C}$.

\section{Adsorption experimental prosedure}

Adsorption experiments carried out include various parameters. These are a total of 6 parameters: different temperature, $\mathrm{pH}$, adsorbent concentration, $\mathrm{MB} 5 \mathrm{G}$ concentration, $\mathrm{H}_{2} \mathrm{O}_{2}$ amount and ultrasonic power effect. A typical experimental procedure performed is as follows. Sorption kinetics studies were carried out in a $250 \mathrm{~mL}$ glass Erlenmeyer in an ultrasonic bath. The deionized water was used in the preparation of the dye solution samples used. The mechanism used in experimental adsorption studies was arranged according to a line on the ultrasonic device. It was subjected to the interaction between the dye and the magnetic nanoparticle for about 15 minutes for the balance of adsorption-desorption. To undergo the adsorption experiments, çömmen kinetic parameters including ultrasonic power of 400 (W) US force, $1.0 \times 10^{-5} \mathrm{M}, 303 \mathrm{~K}, \mathrm{pH} 9$, and adsorbent dose $(0.0020 \mathrm{~g})$. It was taken at certain time intervals during the experimental work to analyze the $3 \mathrm{ml}$ sample. Samples were centrifuged. Absorbance peak changes in the range of 200-900 $\mathrm{nm}$ were tested on the sample with a UV-Vis spectrophotometer (Perkin Elmer Lambda 750). The dye removal efficiency was determined by using the data and using the equation given below(M. Alkan et al., 2008).

$$
\mathrm{q}_{\mathrm{t}}=\left(\mathrm{C}_{0}-\mathrm{C}_{\mathrm{t}}\right) \cdot \mathrm{V} / \mathrm{m}
$$

Where; The terms $\mathrm{C}_{\mathrm{o}}$ and $\mathrm{C}_{\mathrm{t}}\left(\mathrm{mol} . \mathrm{L}^{-1}\right)$ describe the liquid phase concentrations at initial and any time, respectively; qt $\left(\mathrm{mmol}^{-1}\right)$ describes the amount of dyestuff adsorbed per unit mass of the supporting nanoparticle at a given time. The $\mathrm{m}$ indicates the mass of the supporting nanoparticles in solution $(\mathrm{g})$.

\section{RESULTS AND DISCUSSION}

\section{Adsorption effect on removal of MB 5G in ultrasonic process conditions}

The adsorption interaction between MB 5G and bimetallic Pt/Co loaded GO material was tested using the bimetallic Pt/Co loaded $\mathrm{GO}$ adsorbent, ultrasonic wavelength, dye concentrations, $\mathrm{H}_{2} \mathrm{O}_{2}$ concentration, temperatures and $\mathrm{pH}$ parameters. The Analysis datas reflected in Figure 1.

\section{The examined of sorption effect of MB $5 \mathrm{G}$ concentration and bimetallic Pt/Co loaded GO material concentration}

The adsorbent concentration parameter test is one of the most important analyzes in dye removal in an aqueous solution environment. In the adsorption process study, it was determined that the maximum dye removal activity was reached by using $30 \mathrm{mg}$ bimetallic $\mathrm{Pt} / \mathrm{Co}$ loaded $\mathrm{GO}$ absorbance (approximately $84.6 \%$ yield). The analysis data in Figure 1 (a) are reflected. It can express this situation as a result of the increase in the number of active areas due to the increase in surface area(Çiçek et al., 2007). It was determined that the amount of adsorbent used above this value had a negative effect on the amount of dyestuff. This can be expressed as a result of the active sites on the adsorbent surface overlapping each other during the process. Also, the increased amount of adsorbent can have a negative effect on $\mathrm{OH}$ radicals such as scavenging function that may be caused the reduction of removal dye (Sen et al., 2018). One of the other important parameters in adsorption studies is the amount of dye concentration. In this study, the amount of MB 5G Concentration was tested in the range of 24-52 mg. In the adsorption mechanisms, it was determined that the dye concentration contributed significantly to 
the mass transfer resistance between liquid and solid (Savk et al., 2019). In some paper, it was stated that some intermediate molecules formed after the adsorption of $\mathrm{MB} 5 \mathrm{G}$ with $\mathrm{OH}$ radicals cause a negative environment of resistance in dye efficacy (Dindarsafa et al., 2017).

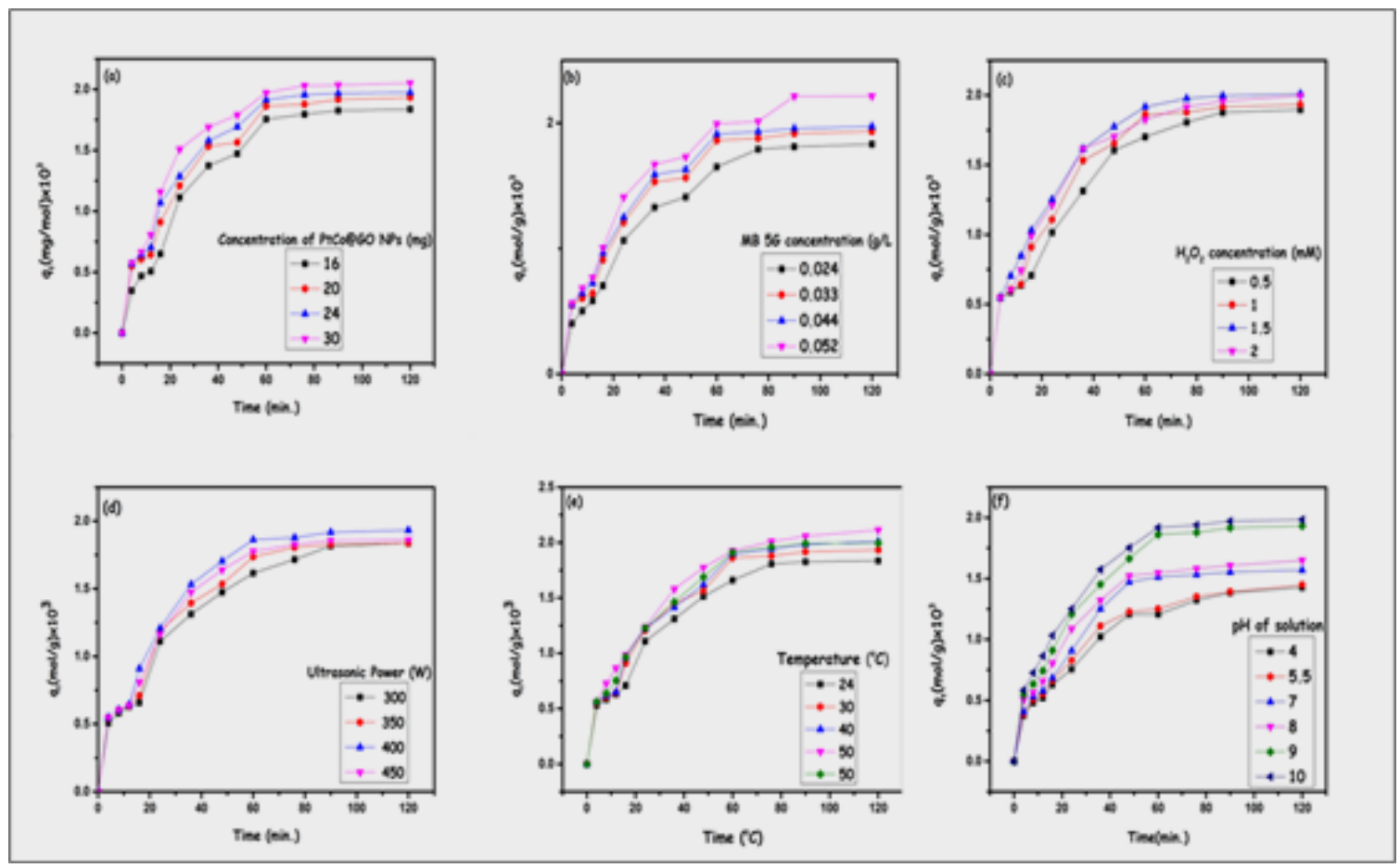

Figure 1. Experimental results of $\mathrm{MB} 5 \mathrm{G}$ removal using bimetallic $\mathrm{Pt} / \mathrm{Co}$ loaded $\mathrm{GO}$ materials at different experimental conditions of (a) Bimetallic Pt/Co loaded GO materials concentrations, (b) $\mathrm{MB} 5 \mathrm{G}$ con., (c) Ultrasonic wave., (d) $\mathrm{H}_{2} \mathrm{O}_{2}$ conc., (e) Temp., (f) pH.

\section{The sorption effects of temperatures, and $\mathrm{pH}$ on the removal of $\mathrm{MB} 5 \mathrm{G}$}

To detect the effects of temperature, five experiments in the range of $24-55{ }^{\circ} \mathrm{C}$ given in Figure 1e. It was determined that the amount of the adsorbed dye increased in parallel with the increasing temperature and the optimum temperature value was determined as $50{ }^{\circ} \mathrm{C}$. The temperature increase of the process medium to the environment leads to increased movement of dye molecules. In this case, the dyestuff used in the study can be explained by providing sufficient energy for the active areas on the surface to interact (Aksu et al., 2000). The increase in the temperature of the environment can cause the pore size of the adsorbent particle to change. This can create a positive synergistic effect in dye removal due to the increase in diffusion rate between the adsorbent and the dye (Khataee et al., 2016). The highest adsorption performance (qm) was detected to be approximately $1150.7 \mathrm{mg} \mathrm{g}^{-1}$ at $50{ }^{\circ} \mathrm{C}$. In addition, the adsoption perfomance of the as-synthesed bimetallic Pt/Co loaded GO material used in this study was compared with other studies in Table 1. As seen the adsorption performance is good when compared the other materials tested in the different dystaffs. Another parameters is $\mathrm{pH}$, and the $\mathrm{pH}$ factor is very important in dye removal in adsorption process mechanisms. $\mathrm{pH}$ value caused the changing charges of adsorbents and the surface charges effect the effectivness of adsorption perfomance. The experments results conducted at different $\mathrm{pH}$ values are given Figure 1f. In adsorption studies, the $\mathrm{pH}$ value of the iso electric point of the adsorbent material has an extremely important effect. In addition, the fact that the $\mathrm{MB} 5 \mathrm{G}$ dye is a cationic dye creates an important effect. A percent dye removal of $64.3 \%$ was obtained at $\mathrm{pH}$ values of 4 . This is result of a reflection resulting from competition between proton ions 
for MB 5G and adsorption sites (Khataee et al., 2015). However, increasing the $\mathrm{pH}$ of the medium resulted in a high dye removal efficiency of $86.2 \%$. It may be explained by the increased interaction of the binding site and its functional groups as a result of enhancing surface area of adsorbent (Mahir Alkan et al., 2005; V. Yönten et al., 2020; Vahap Yönten et al., 2020). In addition, it has made a positive contribution to the increase of $\mathrm{OH}$ radical functions in the environment and to increase the removal of dyestuff. This associated with the increasing the numbers of $\mathrm{OH}$ radicals orginated from $\mathrm{H}_{2} \mathrm{O}_{2}(\mathrm{Nasuha}$ et al., 2010). As a result, it was observed that the $\mathrm{pH}$ factor was extremely effective in MB 5G removal (Figure 5f).

Table1. Comparation adsorption performans of bimetallic Pt/Co loaded on GO materials to some adsorbents tested on the removal different dystuffs.

\begin{tabular}{|c|c|c|}
\hline Adsorbents & Adsorption perfomance, $\mathrm{mg} / \mathrm{g}$ & Reference \\
\hline Activated carbon nanotubes & 399 & (Ma et al., 2012) \\
\hline Nano- $-\mathrm{Fe}_{3} \mathrm{O}_{4}$ & 93.08 & (Iram et al., 2010) \\
\hline Chitosan-graphite oxide & 64.935 & (Zolgharnein et al., 2015) \\
\hline Grafted polyacrylamide on $\mathrm{SiO} 2$ nanocomposites & 378 & (Qin et al., 2015) \\
\hline Turkish Green Clay & 195.74 & (W. Zhao et al., 2015) \\
\hline Graphene & 153.85 & (T. Liu et al., 2012) \\
\hline $\mathrm{Fe}_{3} \mathrm{O}_{4} /$ porous graphene & 460 & (Ghorai et al., 2014) \\
\hline Pt-Co@GO & 1150.7 & This study \\
\hline
\end{tabular}

\section{The sorption effect of $\mathrm{H}_{2} \mathrm{O}_{2}$ cons, and ultrasonic iridations on $\mathrm{MB} 5 \mathrm{G}$ removal}

In the ultrasonic process environment, $\mathrm{H}_{2} \mathrm{O}_{2}$ molecule is an effective factor in dye removal. In ultrasonic systems, it has been observed that $\mathrm{H}_{2} \mathrm{O}_{2}$ concentration has a positive effect on dye removal in active $\mathrm{OH}$ radical increase (Vadivelan et al., 2005). The results showed that the MB 5G removal efficiency was observed to be most efficient in the presence of a $1.5 \mathrm{M} \mathrm{H}_{2} \mathrm{O}_{2}$ concentration (Figure 1c). This can be expressed as a result of the increase in the release of $\mathrm{OH}$ by interacting with the $\mathrm{H}_{2} \mathrm{O}_{2}$ molecule, the propagating waves in processes operating with ultrasonic systems. When the $\mathrm{H}_{2} \mathrm{O}_{2}$ concentration exceeded this value, a noticeable reduction in dye removal efficiency was obtained. As understood in equations (2) and (3), the being of excessive amount of $\mathrm{H}_{2} \mathrm{O}_{2}$ in the reaction medium lead to undesirable consequences such as the scavenging effect of $\mathrm{OH}$ radicals (Bagal et al., 2013).

$$
\begin{array}{ll}
\mathrm{H}_{2} \mathrm{O}_{2}+{ }^{\circ} \mathrm{OH} & \mathrm{H}_{2} \mathrm{O}+\mathrm{HO}_{2}{ }^{\bullet} \\
\mathrm{HO}_{2}{ }^{\cdot}+{ }^{\circ} \mathrm{OH} & \mathrm{H}_{2} \mathrm{O}+\mathrm{O}_{2}
\end{array}
$$

Ultrasonic power effect is another important factor in dye removal systems. (Figure 5d). The increase of ultrasound power effect creates a synergistic effect if dissolution turbans in the adsorption medium. This synergistic effect is positively reflected on the move rate of both reactive radical elements and the dye in the reaction environment(Bae et al., 2013; Q. Wu et al., 2016).

\section{The comparison of some parameters investigated and their re-usability efficiency}

Experimental studies to compare MB 5G removal at different parameter conditions are given in Figure 6a. As indicated in Figure 2a (A), the effect of MB 5G dye removal on ultrasonic and $\mathrm{H}_{2} \mathrm{O}_{2}$, respectively, was tested. As a result of the analysis, the efficiency of dye removal was obtained at approximately $3.25 \%$ and $5.64 \%$. In this case, the conversion coefficient of $\mathrm{H}_{2} \mathrm{O}_{2}$ molecules to free $\mathrm{OH}$ radicals during the Adsorption process is a result of the reflection (as in equation 6) of the death of the $\mathrm{OH}$ radical process. Another reason is that US / Pt/Co loaded on $\mathrm{GO} / \mathrm{H}_{2} \mathrm{O}_{2}$ further increases the surface area by increasing interaction with ultrasonic waves in the presence of process conditions. thus, it 
provides a positive synergistic effect to the removal of dyestuffs(Xu et al., 2012). The stability of the adsorbent used in dye removal using the adsorption method is an important factor in testing the reusability effect (Huang et al., 2014). Five consecutive sample studies were performed on the reusability of magnetic Pt/Co loaded on GO adsorbents in the presence of constant conditions (Figure 2b). As shown in Figure 2b, the nano-adsorbent activity showed that it maintained its activity at approximately $60.2 \%$ after five consecutive experiments. These data showed that Pt/Co loaded on GO adsorbent can be used as an important promoter in dye removal. Figure $2 \mathrm{c}$ shows the variation of the first and last absorption peaks due to the interaction between the Pt/Co loaded on GO and MB 5G in 120 min.

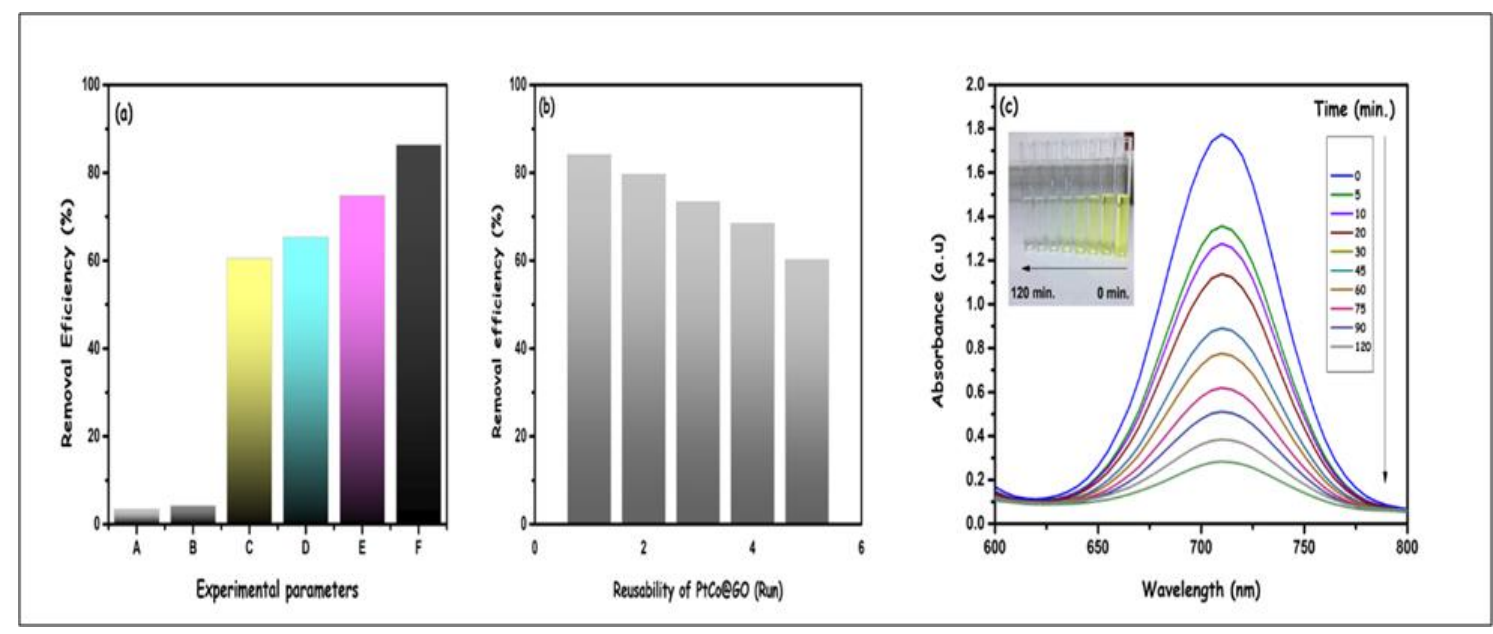

Figure 2. (a) The removal MB $5 \mathrm{G}$ results tested at different conditions using bimetallic $\mathrm{Pt} / \mathrm{Co}$ loaded on GO adsorbents; Ultrasonic iridation (A), cons of $\mathrm{H}_{2} \mathrm{O}_{2}$ (B), cons. of bimetallic Pt/Co loaded on $\mathrm{GO}$ (C), Adsorbent $/ \mathrm{H}_{2} \mathrm{O}_{2}$ (D), adsorbent /Ultrasonic iridation (E), Pt-Co@GO / Ultrasonic iridation $/ \mathrm{H}_{2} \mathrm{O}_{2}(\mathrm{~F})$. (b) recycle of adsorbent in the $\mathrm{MB} 5 \mathrm{G}$ solution. (c) Absorbance: MB 5G at 300-500 nm.

\section{Adsorption kinetic parameters}

Kinetic data are valuable to interpret the adsorption method for determination removal pullutans in water sources. By determinations kinetic data, explaining of the mechanism of adsorption at different kinetic studies begin easier (Huang et al., 2014). In order to understand the reaction state of MB 5G dye removal in the wastewater environment, the so-called first-order kinetic model and the so-called secondorder kinetic model and intra-particle diffusion model analyzes were investigated. In the calculations, the equaitons (7-11) given below were used to interpret the mechanism of adsorpiton MB 5G tested in thi study (Khataee et al., 2017).

$$
\begin{aligned}
& \ln \left(\mathrm{q}_{\mathrm{e}}-\mathrm{q}_{\mathrm{t}}\right)=\ln \mathrm{q}_{\mathrm{e}}-\mathrm{k}_{\mathrm{i}} \mathrm{t} \\
& \frac{t}{q e}=\frac{1}{k_{2} q_{e}^{2}}+\frac{1}{q_{e}} t \\
& t_{1 / 2}=\frac{1}{k_{2} q_{e}} \\
& h=k_{2} q_{e} \\
& q_{t}=k_{\text {int }} t_{1 / 2}+C
\end{aligned}
$$

Where; $t$ and ki explain the time and adsorption rate constant, respectively. The qe and qt quantities describe the amount of the dye (mol.g-1) in the initial and final state, respectively. The data obtained from the kinetic analysis are reflected in Table 1. The 2, 4, and 5 kinetic inequalities are preferred to 
investigate whether the adsorption mechanism is either first-order or second-order, respectively (Hassani et al., 2015). Equations 6 and 11 are preferred to test the half-life of the adsorption process and the initial rate of intra-particle diffusion, respectively(Chen et al., 2014). The expression $\mathrm{k}_{\text {int }}\left(\mathrm{mg}\left(\mathrm{g} \mathrm{min}^{-1 / 2}\right)-1\right.$ in Table 3 explains the intra-particle diffusion rate constant.

Table 2. Kinetic data of magnetic based bimetallic Pt/Co loaded on GO of the MB 5G adsorption.

\begin{tabular}{|c|c|c|c|c|c|c|c|c|c|c|c|c|}
\hline $\bar{T} / K$ & $\begin{array}{c}\text { Pt-Co@GO } \\
\text { dosage } \\
\left(\text { mg.L }{ }^{1}\right)\end{array}$ & $\mathbf{P H}$ & $\begin{array}{c}\text { US power } \\
\text { (W) }\end{array}$ & $\begin{array}{l}\text { MB 5G } \\
\text { mg.L } L^{-1}\end{array}$ & $\begin{array}{c}{\left[\mathrm{H}_{2} \mathrm{O}_{2}\right]} \\
(\mathrm{mM})\end{array}$ & $\begin{array}{c}\text { Pseudo } \\
\text { second-order } \\
\mathbf{R}^{\mathbf{2}}\end{array}$ & $\begin{array}{c}\text { qe (cal.) } \\
\left(\mathrm{mg.g}^{-1}\right) \\
10^{3}\end{array}$ & 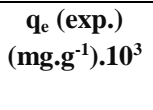 & $\begin{array}{c}\mathrm{k}_{2}(\mathrm{~g} \cdot \mathrm{mg} \\
\left.\mathrm{min}^{-1}\right) \\
10^{11}\end{array}$ & $\mathbf{R}^{2}$ & $\begin{array}{c}\text { h(mol } \\
\left.\min ^{-1} \mathrm{~g}^{-1}\right)\end{array}$ & $\begin{array}{c}\mathbf{t}_{1 / 2} \\
(\mathrm{~min})\end{array}$ \\
\hline 297 & 20 & 9 & 400 & 33 & 1 & 0.59 & 2.29 & 2.28 & 1.52 & 0.99 & 3.46 & 0.288 \\
\hline 303 & 20 & 9 & 400 & 33 & 1 & 0.78 & 2.43 & 2.44 & 1.62 & 0.99 & 3.95 & 0.253 \\
\hline 313 & 20 & 9 & 400 & 33 & 1 & 0.89 & 2.39 & 2.38 & 1.83 & 0.99 & 3.87 & 0.257 \\
\hline 323 & 20 & 9 & 400 & 33 & 1 & 0.70 & 2.65 & 2.65 & 1.5 & 0.99 & 3.98 & 0.251 \\
\hline 333 & 20 & 9 & 400 & 33 & 1 & 0.76 & 2.37 & 2.37 & 2.23 & 0.99 & 5.28 & 0.189 \\
\hline 303 & 20 & 4 & 400 & 33 & 1 & 0.74 & 1.71 & 1.72 & 2.51 & 0.99 & 4.32 & 0.231 \\
\hline 303 & 20 & 5.5 & 400 & 33 & 1 & 0.81 & 1.71 & 1.72 & 2.72 & 0.99 & 4.67 & 0.214 \\
\hline 303 & 20 & 7 & 400 & 33 & 1 & 0.85 & 1.82 & 1.82 & 3.51 & 0.99 & 6.38 & 0.156 \\
\hline 303 & 20 & 8 & 400 & 33 & 1 & 0.89 & 2.03 & 2.03 & 2.11 & 0.99 & 4.28 & 0.233 \\
\hline 303 & 20 & 10 & 400 & 33 & 1 & 0.90 & 2.37 & 2.38 & 2.32 & 0.99 & 5.52 & 0.181 \\
\hline 303 & 20 & 9 & 400 & 24 & 1 & 0.82 & 2.45 & 2.45 & 1.20 & 0.99 & 2.94 & 0.340 \\
\hline 303 & 20 & 9 & 400 & 44 & 1 & 0.73 & 2.23 & 2.24 & 3.36 & 0.99 & 7.52 & 0.132 \\
\hline 303 & 20 & 9 & 400 & 52 & 1 & 0.71 & 2.96 & 2.95 & 1.13 & 0.99 & 3.34 & 0.299 \\
\hline 303 & 16 & 9 & 400 & 33 & 1 & 0.86 & 2.3 & 2.29 & 1.84 & 0.99 & 4.21 & 0.237 \\
\hline 303 & 24 & 9 & 400 & 33 & 1 & 0.75 & 2.44 & 2.45 & 1.82 & 0.99 & 4.45 & 0.224 \\
\hline 303 & 30 & 9 & 400 & 33 & 1 & 0.84 & 2.36 & 2.36 & 2.85 & 0.99 & 6.72 & 0.148 \\
\hline 303 & 20 & 9 & 300 & 33 & 1 & 0.91 & 2.28 & 2.29 & 1.65 & 0.99 & 3.77 & 0.265 \\
\hline 303 & 20 & 9 & 350 & 33 & 1 & 0.74 & 2.27 & 2.27 & 1.88 & 0.99 & 4.26 & 0.234 \\
\hline 303 & 20 & 9 & 450 & 33 & 1 & 0.82 & 2.3 & 2.29 & 1.89 & 0.99 & 4.32 & 0.231 \\
\hline 303 & 20 & 9 & 400 & 33 & 0,5 & 0.75 & 2.38 & 2.37 & 1.72 & 0.99 & 4.07 & 0.245 \\
\hline 303 & 20 & 9 & 400 & 33 & 1.5 & 0.86 & 2.43 & 2.44 & 1.93 & 0.99 & 4.70 & 0.212 \\
\hline 303 & 20 & 9 & 400 & 33 & 2 & 0.91 & 2.40 & 2.41 & 1.84 & 0.99 & 4.43 & 0.225 \\
\hline
\end{tabular}

Table 3. The kinetic results for mechanisim of MB 5G adsorption using bimetallic Pt/Co loaded on GO adsorbents from aquatic solution.

\begin{tabular}{|c|c|c|c|c|c|c|c|c|c|}
\hline & \multicolumn{5}{|c|}{ Mass transfer } & \multicolumn{4}{|c|}{ Intraparticle diffusion } \\
\hline$T / K$ & $\begin{array}{c}\text { Pt-Co@ @GO } \\
\text { mg.L } .^{-1}\end{array}$ & pH & $\begin{array}{c}\text { US } \\
\text { power }(\mathbf{W})\end{array}$ & $\begin{array}{c}{[\mathrm{H2O2}]} \\
(\mathrm{mM})\end{array}$ & $\begin{array}{l}\text { MB 5G } \\
\text { mg.L } L^{-1}\end{array}$ & $\begin{array}{c}\text { kint,1 mg.g }{ }^{-1} \\
\text { min }^{-1 / 2}\end{array}$ & $\mathbf{R}_{1}{ }^{2}$ & $\begin{array}{c}\text { kint }{ }_{, 2} \text { mg.g }^{-1} \\
\text { min }^{-1}\end{array}$ & $\mathbf{R}_{2}{ }^{2}$ \\
\hline 298 & 20 & 9 & 400 & 1 & 33 & 2.189 & 0.94 & 0.0535 & 0.84 \\
\hline 303 & 20 & 9 & 400 & 1 & 33 & 2.282 & 0.92 & 0.0452 & 0.87 \\
\hline 308 & 20 & 9 & 400 & 1 & 33 & 2.345 & 0.99 & 0.0243 & 0.95 \\
\hline 318 & 32 & 9 & 400 & 1 & 33 & 2.533 & 0.93 & 0.0248 & 0.92 \\
\hline 328 & 20 & 9 & 400 & 1 & 33 & 2.465 & 0.96 & 0.0203 & 0.94 \\
\hline 303 & 20 & 4 & 400 & 1 & 33 & 2.189 & 0.91 & 0.0535 & 0.99 \\
\hline 303 & 20 & 5.5 & 400 & 1 & 33 & 1.854 & 0.98 & 0.0532 & 0.99 \\
\hline 303 & 20 & 7 & 400 & 1 & 33 & 2.429 & 0.92 & 0.0248 & 0.91 \\
\hline 303 & 20 & 8 & 400 & 1 & 33 & 2.447 & 0.99 & 0.0294 & 0.92 \\
\hline 303 & 20 & 10 & 400 & 1 & 33 & 2.657 & 0.94 & 0.0432 & 0.98 \\
\hline 303 & 20 & 9 & 400 & 1 & 24 & 1.983 & 0.93 & 0.0256 & 0.97 \\
\hline 303 & 20 & 9 & 400 & 1 & 44 & 2.433 & 0.94 & 0.0244 & 0.92 \\
\hline 303 & 20 & 9 & 400 & 1 & 52 & 2.641 & 0.99 & 0.0365 & 0.96 \\
\hline 303 & 16 & 9 & 400 & 1 & 33 & 2.237 & 0.98 & 0.0379 & 0.97 \\
\hline 303 & 24 & 9 & 400 & 1 & 33 & 2.331 & 0.99 & 0.0287 & 0.98 \\
\hline 303 & 30 & 9 & 400 & 1 & 33 & 2.454 & 0.93 & 0.0341 & 0.99 \\
\hline 303 & 20 & 9 & 300 & 1 & 33 & 2.348 & 0.98 & 0.0364 & 0.98 \\
\hline 303 & 20 & 9 & 350 & 1 & 33 & 2.379 & 0.99 & 0.0356 & 0.98 \\
\hline 303 & 20 & 9 & 450 & 1 & 33 & 2.562 & 0.97 & 0.0324 & 0.95 \\
\hline 303 & 20 & 9 & 400 & 0,5 & 33 & 2.142 & 0.97 & 0.0453 & 0.96 \\
\hline 303 & 20 & 9 & 400 & 1.5 & 33 & 2.346 & 0.92 & 0.0265 & 0.98 \\
\hline 303 & 20 & 9 & 400 & 2 & 33 & 2.423 & 096 & 0.0234 & 0.94 \\
\hline
\end{tabular}




\section{Thermodinamic values of MB 5G adsorption using bimetallic Pt/Co loaded on GO adsorbent}

The constants of rate the adsoption of $\mathrm{MB} 5 \mathrm{G}$ are referenced using Arrhenius Equation 9. In this equation, the $\mathrm{A}$ and $\mathrm{T}$ quantities represent the Arrhenius constant and temperature independent of temperature. As indicated in Figure 3a, the activation energy was determined to be 9.55. So, the adsorption mechanism of MB 5G using bimetallic Pt/Co loaded on GO adsorbent showed that it is physically occurring. Because the activation energy $(5-40 \mathrm{~kJ} / \mathrm{mol})$ explains that the adsorption process proceeds physically. However, if it is above this value, the reaction mechanism shows that it proceeds chemically(Akova et al., 2000; Doğan et al., 2003). Other thermodynamic activation functions such as enthalpy $\left(\Delta \mathrm{H}^{\circ}\right)$, entropy $\left(\Delta \mathrm{S}^{\circ}\right)$ and Gibbs free energy $\left(\Delta \mathrm{G}^{\circ}\right)$ were determined using Eyring equation (10) and equation (11)(Kannan et al., 2001).

$$
\begin{gathered}
\ln k_{2}=\ln A-\frac{E a}{R \cdot T} \\
\ln \left(k_{2} / T\right)=\ln (\mathrm{kb} / h)+\frac{\Delta S}{R}-\frac{\Delta H}{R T}
\end{gathered}
$$

In equation 10, the change in Gibbs energy from the slope $1 / \mathrm{T}$ versus $\ln \left(\mathrm{k}_{2} / \mathrm{T}\right)$ was determined to be $+12.71 \mathrm{~kJ} / \mathrm{mol}$ at $303 \mathrm{~K}$. These results show that the mechanism does not automatically proceed and the process is carried out by transferring energy from an external source. In addition, the standard enthalpy change value was determined as $6.93 \mathrm{~kJ} / \mathrm{mol}$. This implies that the adsorption mechanism takes place endothermicly( Figure 3b).

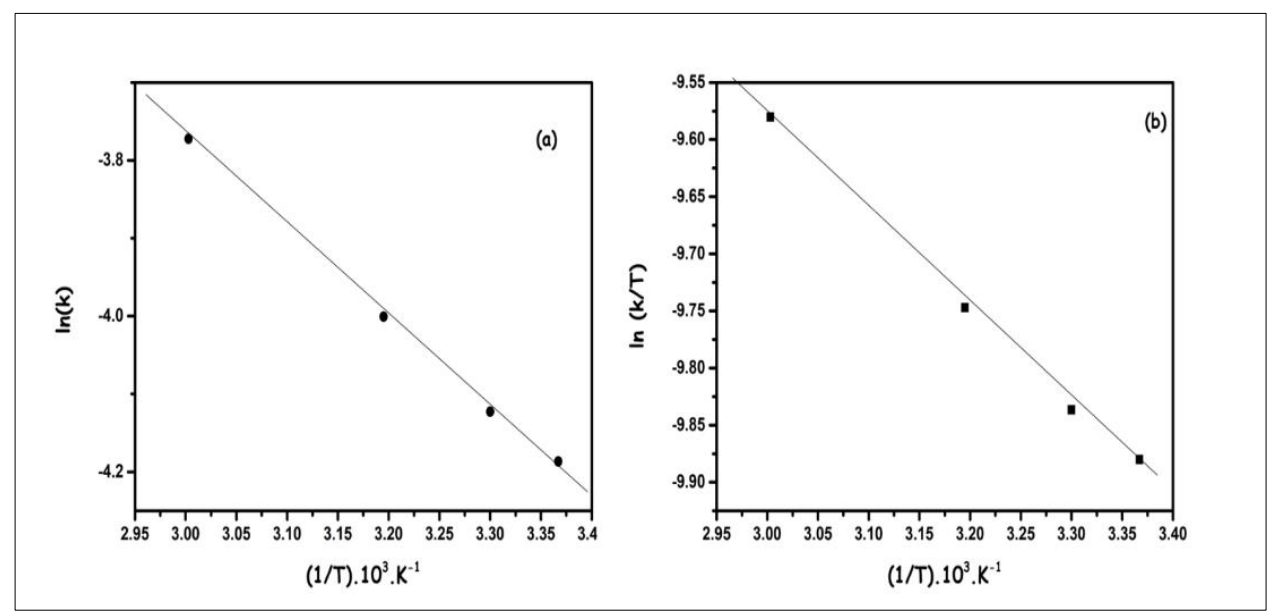

Figure 3. (a) Arrhenius plot and (b) thermodynamic function

\section{CONCLUSION}

In this work, the bimetallic Pt/Co loaded on GO material was produced following a series of simple hydrothermal methods. It was performed in the presence of a number of experimental parameters including the effect of $\mathrm{pH}$, contact time, $\mathrm{H}_{2} \mathrm{O}_{2}$, initial $\mathrm{MB} 5 \mathrm{G}$ dye concentration and temperatures. The most suitable parameters were determined as given below. $30 \mathrm{mg}$ adsorbent amount, $0.052 \mathrm{~g} / \mathrm{L} \mathrm{MB} 5 \mathrm{G}$ amount, $1.5 \mathrm{mM} \mathrm{H}_{2} \mathrm{O}_{2}$ concentration, $400 \mathrm{~W}$ ultrasonic power, $50{ }^{\circ} \mathrm{C}$ temperature and $10 \mathrm{pH}$. At the end of 120 minutes reaction time, $86.4 \%$ dye removal efficiency was obtained in the presence of $\mathrm{pH} 10$. The studied determined that $\mathrm{O}_{2}$ radicals have a synergistic effect on $\mathrm{MB} 5 \mathrm{G}$ dye removal. The kinetics data obtained in the MB 5G adsorption using bimetallic Pt/Co loaded on GO materials were used and adsorption data such as entropy $(\Delta \mathrm{S} *)$, Gibbs free energy $(\Delta \mathrm{G} *)$ and activation energy (Ea) were obtained. The data obtained showed that it was understood that the adsorption reaction mechanism did not occur spontaneously and that the process was an endothermic event. The maximum adsorption 
capacity (qm) of bimetallic Pt/Co loaded on GO material for maxilon blue 5G was found to be 1150.7 $\mathrm{mg} \mathrm{g}^{-1}$. These data showed that bimetallic Pt/Co loaded on GO material proved to be as an effective nano adsorbent as an alternative adsorbent for organic dye removal like MB 5G.

\section{Conflict of Interest}

I declare that there is no conflict of interest during the planning, execution and writing of the article.

\section{Author's Contilbutions}

I hereby declare that the planning, execution and writing of the article was done by me as the sole author of the article.

\section{REFERENCES}

Akova, A, Ustun, G, 2000. Activity and adsorption of lipase from Nigella sativa seeds on Celite at different $\mathrm{pH}$ values. Biotechnology Letters, 22(5), 355-359.

Aksu Z, Tezer, S, 2000. Equilibrium and kinetic modelling of biosorption of Remazol black B by Rhizopus arrhizus in a batch system: Effect of temperature. Process Biochemistry, 36(5), 431-439.

Alkan M, Doğan M, Turhan Y, Demirbaş Ö, Turan P, 2008. Adsorption kinetics and mechanism of maxilon blue 5G dye on sepiolite from aqueous solutions. Chemical Engineering Journal, 139(2), 213-223.

Alkan M, Çelikçcapa S, Demirbaş Ö, Dogan M, 2005. Removal of reactive blue 221 and acid blue 62 anionic dyes from aqueous solutions by sepiolite. Dyes and Pigments, 65(3), 251-259.

Bae S, Kim D, Lee W, 2013. Degradation of diclofenac by pyrite catalyzed Fenton oxidation. Applied Catalysis B: Environmental, 134-135, 93-102.

Bagal MV, Lele BJ, Gogate PR, 2013. Removal of 2,4-dinitrophenol using hybrid methods based on ultrasound at an operating capacity of 7 L. Ultrasonics Sonochemistry, 20(5), 1217-1225.

Banat IM, Nigam P, Singh D, Marchant R. 1996. Microbial decolorization of textile-dye-containing effluents: A review. In Bioresource Technology 58(3), 217-227.

Batra, K, Nayak S, Behura SK, Jani O, 2015. Optimizing performance parameters of chemically-derived graphene/ p -Si heterojunction solar cell. Journal of Nanoscience and Nanotechnology, 15(7), 48774882.

Çalımlı M. H, 2020. Magnetic nanocomposite cobalt-multiwalled carbon nanotube and adsorption kinetics of methylene blue using an ultrasonic batch. International Journal of Environmental Science and Technology, 18(3), 723-740.

Çalımlı MH, Demirbaş, Ö, Aygün A, Alma MH, Nas MS, Şen F, 2018. Immobilization kinetics and mechanism of bovine serum albumin on diatomite clay from aqueous solutions. Applied Water Science, $8(7), 209$.

Chen Z, Fu J, Wang M, Wang X, Zhang J, Xu Q, 2014. Adsorption of cationic dye (methylene blue) from aqueous solution using poly(cyclotriphosphazene-co-4,4'-sulfonyldiphenol) nanospheres. Applied Surface Science, 289, 495-501.

Chiou MS, Ho PY, Li HY, 2004. Adsorption of anionic dyes in acid solutions using chemically cross-linked chitosan beads. Dyes and Pigments, 60(1), 69-84.

Choy KKH, McKay G, Porter JF, 1999. Sorption of acid dyes from effluents using activated carbon. Resources, Conservation and Recycling, 27(1-2), 57-71.

Çiçek F, Özer D, Özer A, Özer A, 2007. Low cost removal of reactive dyes using wheat bran. Journal of Hazardous Materials, 146(1-2), 408-416.

Crini G, 2006. Non-conventional low-cost adsorbents for dye removal: A review. In Bioresource Technology, 97(9), 1061-1085.

Demirbaş Ö, Çalımlı MH, Demirkan B, Alma MH, Nas MS, Khan A, Asiri AM, Şen F, 2019. Thermodynamics, Kinetics, and Adsorption Properties of Biomolecules onto Carbon-Based Materials Obtained from Food Wastes. BioNanoScience, 9(3), 672-682.

Demirbaş Ö, Nas M, 2016. Kinetics and Mechanism of the Adsorption of Methylene Blue from Aqueous Solution onto Turkish Green Clay. Archives of Current Research International, 6(3), 1-10. 
Dindarsafa M, Khataee A, Kaymak B, Vahid B, Karimi A, Rahmani A, 2017. Heterogeneous sono-Fentonlike process using martite nanocatalyst prepared by high energy planetary ball milling for treatment of a textile dye. Ultrasonics Sonochemistry, 34, 389-399.

Doğan M, Alkan M, 2003. Adsorption kinetics of methyl violet onto perlite. Chemosphere, 50(4), 517-528.

Feng X, Zhang Y, Zhou J, Li Y, Chen S, Zhang L, Ma Y, Wang L, Yan X, 2015. Three-dimensional nitrogendoped graphene as an ultrasensitive electrochemical sensor for the detection of dopamine. Nanoscale, 7(6), 2427-2432.

Fonseca AF, Zhang H, Cho K, 2015. Formation energy of graphene oxide structures: A molecular dynamics study on distortion and thermal effects. Carbon, 84(1), 365-374.

Ghorai S, Sarkar A, Raoufi M, Panda A. B, Schönherr H, Pal S, 2014. Enhanced removal of methylene blue and methyl violet dyes from aqueous solution using a nanocomposite of hydrolyzed polyacrylamide grafted xanthan gum and incorporated nanosilica. ACS Applied Materials and Interfaces, 6(7), 47664777.

Haldorai Y, Kim BK, Jo Y. L, Shi, JJ, 2014. Ag@graphene oxide nanocomposite as an efficient visible-light plasmonic photocatalyst for the degradation of organic pollutants: A facile green synthetic approach. Materials Chemistry and Physics, 143(3), 1452-1461.

Hassani A, Soltani RDC, Karaca S, Khataee A, 2015. Preparation of montmorillonite-alginate nanobiocomposite for adsorption of a textile dye in aqueous phase: Isotherm, kinetic and experimental design approaches. Journal of Industrial and Engineering Chemistry, 21, 1197-1207.

Hernández FP, Rojas S, Ocón P, de la Fuente JLG, Terreros P, Peña MA, García-Fierro J L, 2007. An opening route to the design of cathode materials for fuel cells based on PtCo nanoparticles. Applied Catalysis B: Environmental, 77(1-2), 19-28. doi: 10.1016/j.apcatb.2007.07.002

Huang R, Fang Z, Fang X, Tsang EP, 2014. Ultrasonic Fenton-like catalytic degradation of bisphenol A by ferroferric oxide ( $\mathrm{Fe} 3 \mathrm{O} 4)$ nanoparticles prepared from steel pickling waste liquor. Journal of Colloid and Interface Science, 436, 258-266.

Iram M, Guo C, Guan Y, Ishfaq A, Liu H, 2010. Adsorption and magnetic removal of neutral red dye from aqueous solution using Fe3O4 hollow nanospheres. Journal of Hazardous Materials, 181(1-3), 10391050 .

Kannan N, Sundaram MM, 2001. Kinetics and mechanism of removal of methylene blue by adsorption on various carbons - A comparative study. Dyes and Pigments, 51(1), 25-40.

Khataee A, Kayan B, Kalderis D, Karimi A, Akay S, Konsolakis M, 2017. Ultrasound-assisted removal of Acid Red 17 using nanosized Fe3O4-loaded coffee waste hydrochar. Ultrasonics Sonochemistry, 35, 72-80.

Khataee A, Rad TS, Vahid B, Khorram S, 2016. Preparation of zeolite nanorods by corona discharge plasma for degradation of phenazopyridine by heterogeneous sono-Fenton-like process. Ultrasonics Sonochemistry, 33, 37-46.

Khataee A, Saadi S, Safarpour M, Joo S. W, 2015. Sonocatalytic performance of Er-doped ZnO for degradation of a textile dye. Ultrasonics Sonochemistry, 27, 379-388.

Koffi RC, Coutanceau C, Garnier E, Léger JM, Lamy C, 2005. Synthesis, characterization and electrocatalytic behaviour of non-alloyed $\mathrm{PtCr}$ methanol tolerant nanoelectrocatalysts for the oxygen reduction reaction (ORR). Electrochimica Acta, 50(20), 4117-4127.

Lai FJ, Su WN, Sarma LS, Liu, DG, Hsieh CA, Lee JF, Hwang BJ, 2010. Chemical Dealloying Mechanism of Bimetallic Pt-Co Nanoparticles and Enhancement of Catalytic Activity toward Oxygen Reduction. Chemistry - A European Journal, 16(15), 4602-4611.

Liu SH, Zheng FS, Wu JR, 2011. Preparation of ordered mesoporous carbons containing well-dispersed and highly alloying Pt-Co bimetallic nanoparticles toward methanol-resistant oxygen reduction reaction. Applied Catalysis B: Environmental, 108-109, 81-89.

Liu T, Li Y, Du Q, Sun J, Jiao Y, Yang G, Wang Z, Xia Y, Zhang W, Wang K, Zhu H, Wu D, 2012. Adsorption of methylene blue from aqueous solution by graphene. Colloids and Surfaces B: Biointerfaces, 90(1), 197-203.

Liu Y, Liu C. Y, Liu Y, 2011. Investigation on fluorescence quenching of dyes by graphite oxide and graphene. Applied Surface Science, 257(13), 5513-5518.

Liu Z, Liu, Q, Huang Y, Ma Y, Yin S, Zhang X, Sun W, ChenY, 2008. Organic Photovoltaic Devices Based on a Novel Acceptor Material: Graphene. Advanced Materials, 20(20), 3924-3930. 
Ma J, Yu F, Zhou L, Jin L, Yang M, Luan J, Tang Y, Fan H, Yuan Z, Chen J, 2012. Enhanced adsorptive removal of methyl orange and methylene blue from aqueous solution by alkali-activated multiwalled carbon nanotubes. ACS Applied Materials and Interfaces, 4(11), 5749-5760.

Mittal H, Ballav N, Mishra S. B, 2014. Gum ghatti and Fe3O4 magnetic nanoparticles based nanocomposites for the effective adsorption of methylene blue from aqueous solution. Journal of Industrial and Engineering Chemistry, 20(4), 2184-2192.

Nas MS, Gür A, Gür T, Yönten V, 2017. Exploring thermodynamics and kinetic parameters of immobilized catalase enzyme via adsorption on krill clay. Desalination and Water Treatment, 67, 178-186.

Nasuha N, Hameed BH, Din ATM, 2010. Rejected tea as a potential low-cost adsorbent for the removal of methylene blue. Journal of Hazardous Materials, 175(1-3), 126-132.

Novoselov KS, Geim AK, Morozov SV, Jiang D, Zhang Y, Dubonos SV, Grigorieva IV, Firsov AA, 2004. Electric field in atomically thin carbon films. Science, 306(5696), 666-669.

Qin J, Qiu F, Rong X, Yan J, Zhao H, Yang D, 2015. Adsorption behavior of crystal violet from aqueous solutions with chitosan-graphite oxide modified polyurethane as an adsorbent. Journal of Applied Polymer Science, 132(17), 41828.

Roy-Mayhew J D, Aksay IA, 2014. Graphene materials and their use in dye-sensitized solar cells. In Chemical Reviews. 114,12, 6323-6348).

Savk A, Özdil B, Demirkan B, Nas MS, Calimli MH, Alma MH, Inamuddin, Asiri AM, Şen, F. 2019. Multiwalled carbon nanotube-based nanosensor for ultrasensitive detection of uric acid, dopamine, and ascorbic acid. Materials Science and Engineering C, 99, 248-254.

Sen B, Şavk A, Sen F, 2018. Highly efficient monodisperse Pt nanoparticles confined in the carbon black hybrid material for hydrogen liberation. Journal of Colloid and Interface Science, 520, 112-118.

Şen F, Demirbaş Ö, Çalımlı MH, Aygün A, Alma MH, Nas MS, 2018. The dye removal from aqueous solution using polymer composite films. Applied Water Science, 8(7), 206.

Shen J, Shi M, Li N, Yan B, Ma H, Hu Y, Ye M, 2010. Facile Synthesis and Application of Ag-Chemically Converted Graphene Nanocomposite. Nano Res, 3, 339-349.

Singh KP, Mohan D, Sinha S, Tondon GS, Gosh D, 2003. Color removal from wastewater using low-cost activated carbon derived from agricultural waste material. Industrial and Engineering Chemistry Research, 42(9), 1965-1976.

Song Z, Liu W, Wei W, Quan C, Sun N, Zhou Q, Liu G, Wen X, 2016. Preparation and electrochemical properties of $\mathrm{Fe} 2 \mathrm{O} 3 /$ reduced graphene oxide aerogel ( $\mathrm{Fe} 2 \mathrm{O} 3 / \mathrm{rGOA})$ composites for supercapacitors. Journal of Alloys and Compounds, 685, 355-363.

Teixeira SR, Lloyd C, Yao S, Andrea SG, Whitaker IS, Francis L, Conlan, RS, Azzopardi E, 2016. Polyaniline-graphene based $\alpha$-amylase biosensor with a linear dynamic range in excess of 6 orders of magnitude. Biosensors and Bioelectronics, 85, 395-402.

Vadivelan V, Vasanth, KK, 2005. Equilibrium, kinetics, mechanism, and process design for the sorption of methylene blue onto rice husk. Journal of Colloid and Interface Science, 286(1), 90-100.

Wu Q, Zhang H, Zhou, L, Bao C, Zhu H, Zhang Y, 2016. Synthesis and application of rGO/CoFe2O4 composite for catalytic degradation of methylene blue on heterogeneous Fenton-like oxidation. Journal of the Taiwan Institute of Chemical Engineers, 67, 484-494.

Wu R, Liu JH, Zhao L, Zhang X, Xie J, Yu B, Ma X, Yang ST, Wang H, Liu Y, 2014. Hydrothermal preparation of magnetic Fe3O4@C nanoparticles for dye adsorption. Journal of Environmental Chemical Engineering, 2(2), 907-913.

Xu L, Wang J, 2012. Fenton-like degradation of 2,4-dichlorophenol using Fe $3 \mathrm{O} 4$ magnetic nanoparticles. Applied Catalysis B: Environmental, 123-124, 117-126.

Yagub MT, Sen TK, Afroze S, Ang HM, 2014. Dye and its removal from aqueous solution by adsorption: A review. In Advances in Colloid and Interface Science. 209, 172-184.

Yener J, Kopac T, Dogu G, Dogu T, 2006. Adsorption of Basic Yellow 28 from aqueous solutions with clinoptilolite and amberlite. Journal of Colloid and Interface Science, 294(2), 255-264.

Yenisoy KS, Aygün A, Güneş M, Tahtasakal E, 2004. Physical and chemical characteristics of polymerbased spherical activated carbon and its ability to adsorb organics. Carbon, 42(3), 477-484.

Yönten V, Özgüven A, Ahmed AA, Akçay ME, 2020. Effect of some medium parameters on Brilliant Blue $\mathrm{G}$ biosorption by Amberlite resin/Agaricus campestris. International Journal of Environmental Science and Technology, 1-10. 
Yönten, Vahap, Sanyürek NK, Kivanç MR, 2020. A thermodynamic and kinetic approach to adsorption of methyl orange from aqueous solution using a low cost activated carbon prepared from Vitis vinifera L. Surfaces and Interfaces, 20, 100529.

Zhang X, Zhang P, Wu Z, Zhang L, Zeng G, Zhou C, 2013. Adsorption of methylene blue onto humic acidcoated Fe3O4 nanoparticles. Colloids and Surfaces A: Physicochemical and Engineering Aspects, 435, 85-90.

Zhao J, Manthiram A, 2011. Preleached Pd-Pt-Ni and binary Pd-Pt electrocatalysts for oxygen reduction reaction in proton exchange membrane fuel cells. Applied Catalysis B: Environmental, 101(3-4), 660668.

Zhao W, Tang Y, Xi J, Kong J, 2015. Functionalized graphene sheets with poly(ionic liquid)s and high adsorption capacity of anionic dyes. Applied Surface Science, 326, 276-284.

Zolgharnein J, Bagtash M, Shariatmanesh T, 2015. Simultaneous removal of binary mixture of Brilliant Green and Crystal Violet using derivative spectrophotometric determination, multivariate optimization and adsorption characterization of dyes on surfactant modified nano- $\gamma$-alumina. Spectrochimica Acta - Part A: Molecular and Biomolecular Spectroscopy, 137, 1016-1028. 